\title{
DOES MANDATORY INTEGRATED REPORTING AFFECT STOCK PRICES? AN EMPIRICAL STUDY ON THE JOHANNESBURG STOCK EXCHANGE
}

\author{
ZORUNLU ENTEGRE RAPORLAMA HISSSE SENEDİ FIYYTLARINI \\ ETKILLR Mİ? JOHANNESBURG BORSASI ÜZERINNE AMPİRIK BİR \\ ÇALIŞMA
}

\section{A.R. Zafer SAYAR* Metin Can TOPDEMİR ${ }^{* *}$}

\begin{abstract}
Integrated Reporting (IR) is one of the new reporting phenomena that has gained widespread attention over the last decade because of the growing demand for non-financial forward-looking information. It combines financial and non-financial information such as governance and social information under one report. Even though this implementation framework has been published, there is a need to address its effects on share prices and earnings per share ratio from an analytical perspective. In this paper, we have adopted a panel data analysis to test the effects of mandatory IR implementation on companies listed in the Johannesburg Stock Exchange. The connection was established through a panel data analysis on two separate models composed of financial ratios, between the years of 2007 and 2016 using a dummy variable starting from 2011 to incorporate the commencement of mandatory IR. We conclude that compulsory Integrated Reporting has a statistically meaningful relationship with both the share price and earnings per share ratio of companies.

Keywords: Integrated reporting, Stock price valuation, Earnings per share, Johannesburg Stock Exchange

JEL Classification: G10, G15, G18, M40, M48

\section{Özet}

Entegre Raporlama kurumsal dünyada son birkaç yıl içinde finansal olmayan geleceğe dönük verilerin raporlaması hususunda artan talepten dolayı dikkati çeken yeni raporlama olgularından biridir. Bu raporlama finansal ve finansal olmayan yönetişim ve sosyal öğeleri tek bir rapor altında bir araya getirmektedir. Uygulama çerçevesinin yayınlanmış olmasına rağmen hisse senedi fiyatları ve hisse başı kazanç üzerindeki etkisi ve uygulanabilirliğinin ele alınması gerekmekte olup literatürde henüz analitik bir çalışma mevcut

* Associate Prof. Dr., TOBB University of Economics \&Technology, Faculty of Economics and Administrative Sciences, 0000-0002-2731-8209.

** CPA, Ph.D. Candidate, Hacettepe University, Graduate School of Social Sciences, 0000-0002-4859-208X
\end{abstract}


değildir. Bu çalışmada panel veri analizi ile zorunlu Entegre Raporlamanın, Johannesburg Borsasında hisse senetleri işlem gören firmaların üzerindeki etkileri araştırılmıştır. Bu ilişki, 2007 ve 2016 yılları arasındaki finansal oranlarla oluşturulan iki farklı modele panel veri analizi ve 2011 yılından itibaren gölge değişken kullanılarak uygulanmasıyla elde edilmiştir. Elde edilen sonuçlar Entegre Raporlama zorunluluğunun hisse senedi fiyatları ve hisse başı kazanç ile istatistiksel olarak anlamlı bir ilişki içinde olduğunu göstermektedir.

Anahtar Kelimeler: Entegre raporlama, Hisse senedi değerlemesi, Hisse başı kazanç, Johannesburg Borsası

JEL Sınıflandırma: G10, G15, G18, M40, M48

\section{Introduction}

In the last decade, the perception of "value" in the business world has been in an ever-evolving stage. As a result of this, the market valuation of organizations started to be more composed of intangible assets in comparison to tangible assets. Along with this shift in the understanding of "value" the dynamics of the global economy started to change.

The main reason behind the increasing demand for non-financial information and metrics regarding social and environmental impacts (Stewart, 2015) is the shift in the market capitalization of S\&P 500 companies to become more intangible asset-weighted (Eccles, Serafeim, \& Krzus, 2011). Accordingly, the days where the financial performance of an organization is the mere measure of worth has passed (Burke \& Clark, 2016). Figure 1 presents the shift of market valuation components from tangible assets to intangible assets in a striking manner. As it can be read from Figure 1, Intangible Assets represented only \%17 of the total market valuation of the S\&P companies back in 1975 whereas in 2015 it grew to become $\% 84$.

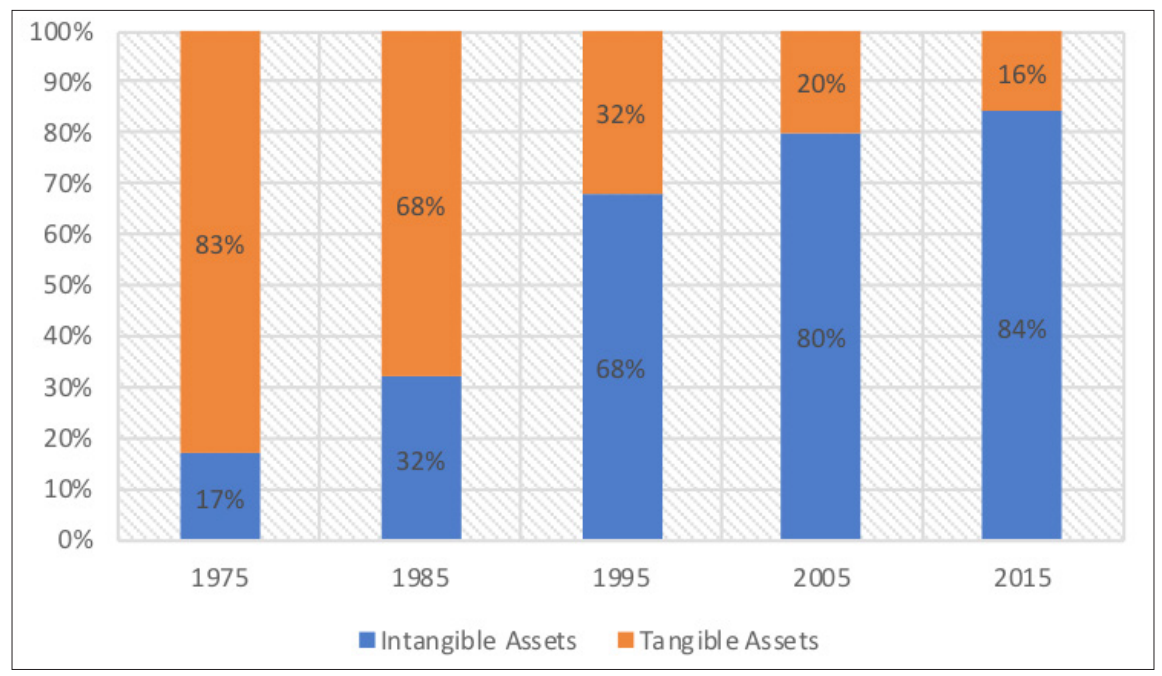

Figure I: Components of S\&P 500 Market Value (Ocean Tomo, n.d.) 
Thus, it is safe to say that influence of intangible assets on competitiveness has increased and their effective management became a crucial component to address for sustainable value creation process of organizations. In this manner, Eccles and Serafeim (2013) define sustainability as “...in terms of a company's strategy and the relationship between this strategy and the society that grants companies their license to operate". Consequently, they point out that a sustainable strategy should create value for both the organization and the society (Eccles \& Serafeim, 2013).

Considering these developments, organizations started to voluntarily publish corporate sustainability reports that communicate non-financial information. However, due to lack of regulation and guidance, these reports fell short of meeting expectations and merely became supplements to the annual financial reports (Eccles \& Krzus, 2010).

The call to vary Corporate Reporting and disclosure of non-financial information found an answer when in 2010 International Integrated Reporting Council (IIRC) was founded and introduced the Integrated Reporting (IR) framework in 2011 (Havlová, 2015). IR became the logical consequence of the call for non-financial information disclosure and corporate responsibility issues (Marin-Garcia \& Tomas, 2016).

\section{Integrated Reporting in South Africa}

The corporate governance in South Africa during the early 1990s was at a minimal level. Mainly, large corporations were family owned and an emphasis on corporate governance was not existent (Schulschenk, 2012). The establishment of Institute of Directors in Southern Africa (IoDSA) in 1992, which was commissioned by the King Committee, marks the beginning of Corporate Governance studies in South Africa since the sole purpose of this institutions was to promote corporate governance studies to launch the Southern African economy in the global context (Eccles, Serafeim, \& Armbrester, 2012).

The committee has issued its first report King I in 1994, which has outlined that a focus of a company should shift from maximizing book value to maximizing economic value while considering needs and expectations of all the stakeholders (Schulschenk, 2012). In 2002, following the World Summit on Sustainable Development in Johannesburg, the first king code was revised and King Code II was published (King Comittee, 2002). In addition to the first code, King Code II has introduced concepts of risk management and sustainability. This report indicated that companies should not be operating with the solitary purpose of financial profit but should also consider its economic, environmental and social outcomes (King Comittee, 2009).

Along with IIRC, which has published the integrated reporting framework, the King Report on Governance for South Africa became a separate formation that undertook this concept (MarinGarcia \& Tomas, 2016). The step towards compulsory reporting was taken with the King Code III in 2010 (IoDSA, 2013). Accordingly, in 2010 Johannesburg Stock Exchange modified its listing requirements to include the recommendations put forward by the King III report. Consequently, 450 
listed companies were obliged to issue an integrated report for the prospective fiscal years in place of the annual financial and sustainability reports (Eccles et al., 2011).

\section{Literature Review}

This paper examines the relationship between IR, share price valuations and earning per share through financial ratios derived from corporations listed on the South African Johannesburg Stock Exchange. To be able to test this relationship we have utilized two different econometric panel data models with IR function being the dummy variable.

IIRC strongly argues that components of IR framework will maximize the effectiveness of capital distribution in the financial markets by ensuring better quality information disclosure to prospective investors. Under this context, we predict that both share price valuation and earnings per share ratio are positively associated with the IR reporting presence of corporations.

One of the important changes that have already begun is the increasing demand and emphasis on non-financial information. Demand regarding disclosure of non-financial information containing Environmental, Social, and Governance (ESG) performance from the investors has been growing (Eccles et al., 2011). However, in the current form of financial reporting, which can be considered as the main source of decision making for investors, the value of intangible assets like human capital, brand value, natural resources, $R \& D$ and intellectual capital is not present.

Pursuantly, traditional corporate financial reporting structure was challenged as an inefficient and a non-satisfactory tool following the global economic crisis. The main emphasis was that the current form of financial reporting only provides information about the past and investors were looking for prospective outlook as well (Flower, 2015). Heretofore, with John Elkington's concept of triple bottom line, emphasis on organization's impact on social, economic and environmental areas gained widespread attention during the late 1990s and early 2000s (Dumay, Bernardi, Guthrie, \& Demartini, 2016).

Under this context there have been many studies that have analyzed and examined the nonfinancial reporting undertaken by corporations (Maas, Schaltegger, \& Crutzen, 2016) and it has been determined that reporting of non-financial capital utilized by corporations such as human and natural should be reported in a manner which underlines how they are being utilized to support long-term corporate sustainability (Beck, Dumay, \& Frost, 2017). The long-term sustainability of a company, from a financial point of view, can be expressed as the ability to continuously maximize wealth for its shareholders.

This idea of full disclosure supports the theory of full efficiency in the decision-making process of investors. Accordingly, in the ever-changing global markets, only the investors who possess all of the data during the decision-making process may succeed (Fărcas, 2015). Possession of full data in return, will correct the stock price valuations and ensure the fair distribution of the capital 
(Rikanovic, 2005). It has been determined that there is an empirical relationship between investors of a stock and the volatility of that stock. Accordingly, long-term institutional investors prefer to buy stocks of companies which provide frequent, meaningful and transparent disclosures (Bushee \& Christopher, 2000).

The main research agenda of financial economics has always been the estimation of stock prices and stock price returns. Accordingly, it has been widely accepted that stock price valuation has predictable components (Kothari \& Shanken, 1997; La Porta, 1996). There has been a lot of studies supporting these results, Ang and Bekaert (2006) have concluded that stock price predictability is more efficient and short-term rather than long-term.

In a fully efficient capital market, all stock prices should reflect the available information in a full and objective manner at fair value. Even though there have been a lot of studies that prove the viability of this theory, there has been an increasing number of studies that aim to prove its invalidity. The main reason behind these studies is that the price-earnings ratios reflect the future investment decisions (Basu, 1977). Even though Kendall (1953) has determined in his study that stock prices oscillate over time, Kendall's other progenitor studies on efficient markets focused on using past data to estimate future stock prices (Lewellen, 2004).

The current literature for stock prices indicates a variance between the intrinsic value of a stock and its market price. This variance acts as an input for the decision-making process of the investors $(\mathrm{Ou}$ \& Penman, 1989). Accordingly, analysts rely heavily on the expected rate of growth on revenue while neglecting the intrinsic value of stocks (Easton, 2004). The current consensus is that there exists a positive and linear relationship between past earnings and stock prices (Molodovsky, 1955).

The current studies mainly rely on predictive regression models to estimate the stock prices (Gupta \& Modise, 2012). Even though there are certain econometric challenges concerning predictive regression models (Gregory Mankiw \& Shapiro, 1986; Kirby, 1997), the general accord is that they are effective to be used in future stock price estimation modelings (Campbell, 1999).

As of yet, there has not been any empirical study on the effects of Integrated Reporting on stock prices and earnings per share ratio. However, Baboukardos and Rimmel's (2016) study showed a positive relationship between mandatory IR and market capitalization of companies listed in the Johannesburg Stock Exchange.

The existing literature includes different studies that examine the relationship between Earnings Per Share and Stock Price Valuation with different independent variables. However, there has not been any study that used IR as a dummy variable to measure its effect. 


\section{Research and Empirical Study}

\section{I. Data and Limitations}

We have used 10 years of data observations derived from the 30 companies listed in Table 1 below for the years between 2007 and 2016. We have excluded companies that have not been traded on the stock exchange for a continuous 10-year period due to bankruptcy, merger or corporate split. Additionally, we are aware that there might have been effects of the 2008-2009 financial global crises on the data and this effect should be carefully evaluated and tested separately.

Table I: Industrial Distribution of the Companies used in the Empirical Study

\begin{tabular}{|l|l|}
\hline Industry & Number of Companies \\
\hline Industrial Metals \& Minerals & 6 \\
\hline Retail & 5 \\
\hline Precious Materials \& Minerals & 2 \\
\hline Real Estate & 2 \\
\hline Communication Services & 2 \\
\hline Basic Materials & 2 \\
\hline FMCG & 2 \\
\hline Energy & 1 \\
\hline Holding & 1 \\
\hline Production of Medical Drugs & 1 \\
\hline Consumer Cyclical & 1 \\
\hline Production of Paper \& Related Products & 1 \\
\hline Production of Cosmetics & 1 \\
\hline Production of Tobacco-Related Products & 1 \\
\hline Healthcare & 1 \\
\hline Insurance & 1 \\
\hline Total & $\mathbf{3 0}$ \\
\hline
\end{tabular}

Data used in the empirical study is composed of financial information derived from the websites of the companies listed below for the years between 2007 and 2016. The use of special accounting periods is common in South Africa and accordingly, the fiscal year of the company may end and start either in March, June, September or December.

The banking and finance industry has been excluded from this study. Sector-specific financial ratios should be considered for this particular industry in the prospective studies. The effects of IR on stock prices and earnings per share of financial institutions should be evaluated with a separate study. 
Table 2: Research Sample

\begin{tabular}{|l|l|l|l|}
\hline No \# & Company Name & No \# & Company Name \\
\hline 1 & Kumba Iron Ore & 16 & MTN Group Ltd \\
\hline 2 & Oceana Group LTD & 17 & Nampak Ltd \\
\hline 3 & Liberty Holdings LTD & 18 & Netcare Ltd \\
\hline 4 & Sasol Ltd & 19 & Sappi Ltd \\
\hline 5 & The Foschini Group Ltd & 20 & Telkom SA SOC Ltd \\
\hline 6 & Truworths International Ltd & 21 & Woolworths Holdings Ltd \\
\hline 7 & Anglo American Plc & 22 & Tiger Brands Ltd \\
\hline 8 & AngloGold Ashanti Ltd & 23 & African Rainbow Minerals Ltd \\
\hline 9 & Aspen Pharmacare Holdings Ltd & 24 & BHP Billiton Plc \\
\hline 10 & Barloworld Ltd & 25 & British American Tobacco Plc \\
\hline 11 & Exxaro Resources Ltd & 26 & Imperial Holdings Ltd \\
\hline 12 & Gold Fields Ltd & 27 & Northam Platinum Ltd \\
\hline 13 & Impala Platinum Holdings Ltd & 28 & Clicks Group Ltd \\
\hline 14 & Intu Properties Plc & 29 & Pick n Pay Stores Ltd \\
\hline 15 & Massmart Holdings Ltd & 30 & Distell Group Ltd \\
\hline
\end{tabular}

Additionally, financial ratios utilized in the study are listed in Table 3. The calculation details of the ratios can be observed from the table. The data used to calculate these ratios, independent variables in our model, is derived from the audited financial statements that are disclosed for investors for the years between 2007 and 2016. The dependent variables for our models are Earnings Per Share and Stock Price Valuation. These dependent variables are posted in two different models.

Table 3: Financial Ratios used as Independent Variables

\begin{tabular}{|l|l|l|l|}
\hline No \# & Variable Name & Symbol & Calculation \\
\hline 1 & Earnings Per Share & EPS & Net Income / Outstanding Shares \\
\hline 2 & Net Earnings Margin \% & NEM & Net Income / Sales Revenue \\
\hline 3 & Operating Margin \% & OPM & Net Operating Income / Sales Revenue \\
\hline 4 & Return on Assets \% & ROA & Net Income / Total Assets \\
\hline 5 & Return on Equity \% & ROE & Net Income / Shareholder's Equity \\
\hline 6 & Year over Year Growth & YYG & (Current Year Revenue - Previous Year Revenue) / Current Year Revenue \\
\hline 7 & Current Ration & CUR & Current Assets / Current Liabilities \\
\hline 8 & Financial Leverage & FIL & Total Debt / Total Assets \\
\hline 9 & Quick Ration & QUR & (Current Assets - Inventory)/ Current Liabilities \\
\hline 10 & Debt/Equity Ratio & DEB & Total Debt / Shareholder's Equity \\
\hline 11 & Receivables Turnover & RET & Sales Revenue / Average Total Receivables \\
\hline 12 & Inventory Turnover & INV & Cost of Goods Sold / Average Inventory \\
\hline 13 & Asset Turnover & AST & Sales Revenue / Average Total Assets \\
\hline 14 & Mandatory Integrated Reporting & EZR & \\
\hline 15 & Stock Price & HSF & \\
\hline
\end{tabular}




\subsection{Research Hypothesis and Models}

The main hypothesis of this study is founded on the positive relationship between mandatory IR disclosure and firm valuations, which is represented through "Earnings per Share" and "Stock Price Valuation" variables. In this context hypothesis zero $\left(H_{0}\right)$ should be empirically tested and verified.

Main and the null hypothesis of the study are presented below;

$\mathrm{H}_{0}$ : Financial Ratios have no effect on Earnings per Share and Stock Price Valuations of Companies.

$\mathrm{H}_{1}$ : Financial Ratios have an effect on Earnings per Share and Stock Price Valuations of Companies.

In order to test these hypotheses, the research models below are used;

1. Research Model: $E P S_{i t}=\beta_{0}+\beta_{1} N E M_{i t}+\beta_{2} O P M_{i t}+\beta_{3} R O A_{i t}+\beta_{4} R O E_{i t}+\beta_{5} Y Y G_{i t}+\beta_{6} C U R_{i t}+\beta_{7} F I L L_{i t}$ $+\beta_{8} Q U R_{i t}+\beta_{9} D E B_{i t}+\beta_{10} R E T_{i t}+\beta_{11} I N V_{i t}+\beta_{12} A S T_{i t}+\beta_{13} E Z R_{i t}+\varepsilon_{i t}$

2. Research Model: HSFit $=\beta_{0}+\beta_{1} N E M_{i t}+\beta_{2} O P M$ it $+\beta_{3} R O A_{i t}+\beta_{4} R O E_{i t}+\beta_{5} Y Y G_{i t}+\beta_{6} C U R_{i t}+$ $\beta_{7} F I L L_{i t}+\beta_{8} Q U R_{i t}+\beta_{9} D E B_{i t}+\beta_{10} R E T_{i t}+\beta_{11} I N V_{i t}+\beta_{12} A S T_{i t}+\beta_{13} E Z R_{i t}+\varepsilon_{i t}$

Subsequently, some of the financial ratios utilized in this study are calculated using the same denominator, which may suggest multicollinearity between independent variables and correlation problems. In the light of these, a factor analysis is adapted to determine multicollinearity between variables. High multicollinearity variables will be tested to form composite independent variables to eliminate the correlation problem.

The factor analysis is completed with IBM SPSS 23.0 version. Principal components method and varimax rotation techniques are adapted to carry out the factor analysis. The main objective of this technique is to group the independent variables under a limited number of composite variables as possible.

$\mathrm{KMO}$ and Bartlett tests are used to determine sample adequateness of the study and suitability of the data matrix to the rotation technique before factor analysis is implemented. The related statistics of these tests are presented below in Table 4.

Table 4: KMO and Bartlett Test Statistics

\begin{tabular}{|l|l|l|}
\hline \multicolumn{2}{|l|}{ Kaiser-Meyer-Olkin Measure of Sampling Adequacy } &, 597 \\
\hline \multirow{3}{*}{ Bartlett's Test of Sphericity } & Approx. Chi-Square & 1252,567 \\
\cline { 2 - 3 } & Df & 66 \\
\cline { 2 - 3 } & Sig. & 0,000 \\
\hline
\end{tabular}

The statistical results suggest that Kaiser Meyer sample adequacy statistics is below 0,5 and that the sample size is satisfactory. Additionally, it has been observed that the Bartlett test statistics is statistically meaningful at a \%95 confidence level. 
Consequently, the scree plot graph is used to determine the proper number of factors for the factor analysis process.

The scree plot graph can be observed in Figure 2.

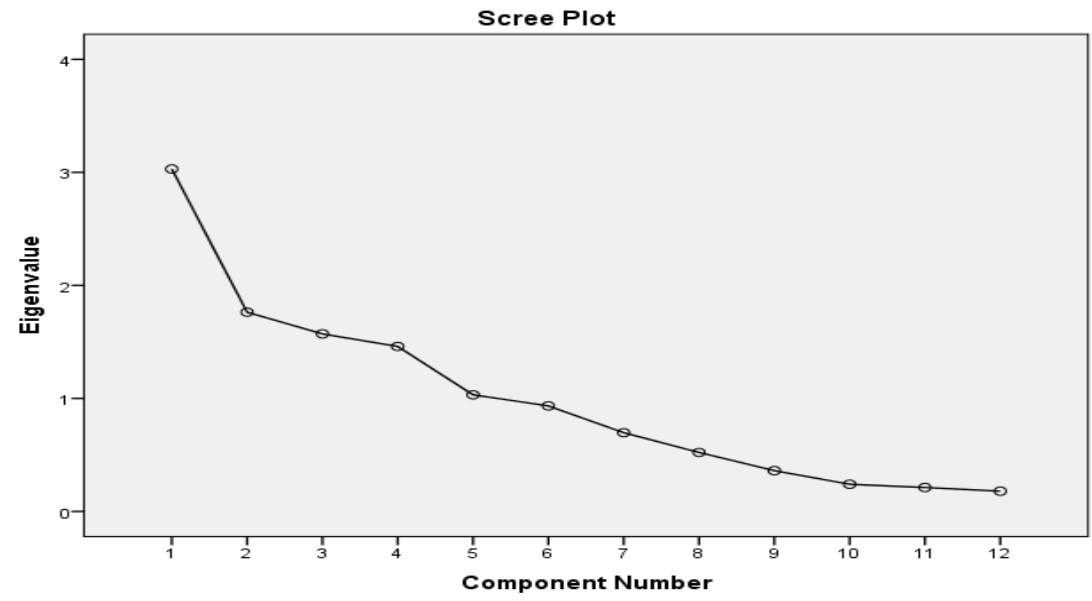

Figure 2: Factor Analysis Scree Plot Graph

Once the graph is examined it can be observed that the Eigenvalue rate decreases after the fifth factor. Accordingly, it can be stated that a 5-factor disposition would be favorable for the factor analysis. Before deciding on the number of factors to be used variance rates can be evaluated as well. The variance rates that can be explained by a number of factors are illustrated below in Table 5 .

Table 5: Expounded Variance Rates

\begin{tabular}{|c|c|c|c|c|c|c|c|c|c|}
\hline \multirow[t]{2}{*}{ Factor } & \multicolumn{3}{|c|}{ Primary Eigenvalue } & \multirow{2}{*}{\begin{tabular}{|l|}
$\begin{array}{l}\text { Derive } \\
\text { Square }\end{array}$ \\
Tot.
\end{tabular}} & \multicolumn{2}{|c|}{ Weighted Sum of } & \multicolumn{3}{|c|}{ Rotated Weighted Sum of Squares } \\
\hline & Tot. & \% Var. & Cum \% & & $\%$ Var. & Cum \% & Tot. & $\%$ Var. & Cum \% \\
\hline 1 & 3,03 & 25,248 & 25,248 & 3,03 & 25,248 & 25,248 & 1,968 & 16,396 & 16,396 \\
\hline 2 & 1,763 & 14,692 & 39,939 & 1,763 & 14,692 & 39,939 & 1,954 & 16,281 & 32,677 \\
\hline 3 & 1,571 & 13,091 & 53,031 & 1,571 & 13,091 & 53,031 & 1,891 & 15,755 & 48,432 \\
\hline 4 & 1,46 & 12,163 & 65,193 & 1,46 & 12,163 & 65,193 & 1,782 & 14,847 & 63,28 \\
\hline 5 & 1,032 & 8,598 & 73,791 & 1,032 & 8,598 & 73,791 & 1,261 & 10,511 & 73,791 \\
\hline 6 & 0,934 & 7,781 & 81,573 & & & & & & \\
\hline 7 & 0,697 & 5,806 & 87,378 & & & & & & \\
\hline 8 & 0,522 & 4,349 & 91,727 & & & & & & \\
\hline 9 & 0,361 & 3,008 & 94,736 & & & & & & \\
\hline 10 & 0,241 & 2,006 & 96,742 & & & & & & \\
\hline 11 & 0,212 & 1,764 & 98,506 & & & & & & \\
\hline 12 & 0,179 & 1,494 & 100 & & & & & & \\
\hline
\end{tabular}


As it can be observed from the Table first and second factors are able to account for $\% 16$ of the total variance. Additionally, third and fourth factors can account for $\% 15$, whereas the fifth factor can account for $\% 10$ of the variance. In total five factors can account for $\% 74$ of the total variance. The total being above $\% 70$ is a favorable rate for factor analysis.

The five-factor structure and inter independent variable grouping with factor loads can be observed in Table 6.

Table 6: Rotation Factor Matrix

\begin{tabular}{|c|c|c|c|c|c|}
\hline \multicolumn{6}{|c|}{ Component } \\
\hline & 1 & 2 & 3 & 4 & 5 \\
\hline ROE & 0.781 & & & & \\
\hline ROA & 0.762 & & & & \\
\hline YYG & 0.632 & & & & \\
\hline OP & & 0.936 & & & \\
\hline NM & & 0.902 & & & \\
\hline QUR & & & 0.918 & & \\
\hline CUR & & & 0.913 & & \\
\hline DEB & & & & 0.886 & \\
\hline FILL & & & & 0.775 & \\
\hline RET & & & & & \\
\hline AST & & & & & 0.595 \\
\hline INV & & & & & 0.561 \\
\hline
\end{tabular}

Based on factor loads presented below, each factor has a load more than 0,5 and the first factor is composed of 3 independent variables whereas the rest of the factors are composed of 2 independent variables. Factors and independent variable couplings are presented in the Table below.

Table 7: Factor Independent Variable Couplings

\begin{tabular}{|l|l|}
\hline Factor & Independent Variable \\
\hline \multirow{4}{*}{ F1 } & ROE \\
\cline { 2 - 2 } & ROA \\
\cline { 2 - 2 } & YYG \\
\hline \multirow{2}{*}{ F2 } & OP \\
\cline { 2 - 2 } & NM \\
\hline \multirow{2}{*}{ F3 } & QUR \\
\cline { 2 - 2 } & CUR \\
\hline \multirow{2}{*}{ F4 } & DEB \\
\cline { 2 - 2 } & FILL \\
\hline \multirow{2}{*}{ F5 } & AST \\
\cline { 2 - 2 } & INV \\
\hline
\end{tabular}


The models are updated based on the factor structure explained above are as follows;

$E P S_{i t}=\beta_{0}+\beta_{1} F 1_{i t}+\beta_{2} F 2_{i t}+\beta_{3} F 3_{i t}+\beta_{4} F 4_{i t}+\beta_{5} F 5_{i t}+\beta_{6} E Z R_{i t}+\varepsilon_{i t}$

$H S F_{i t}=\beta_{0}+\beta_{1} F 1_{i t}+\beta_{2} F 2_{i t}+\beta_{3} F 3_{i t}+\beta_{4} F 4_{i t}+\beta_{5} F 5_{i t}+\beta_{6} E Z R_{i t}+\varepsilon_{i t}$

\subsubsection{Cross-Sectional Dependency Evaluation}

The independent variables are tested for cross-dependency before determination of stationarity of independent variables through unit root tests. These are important to understand the structure of the data and the further methods that will be implemented for unit root tests. The existence of crosssectional dependency has a great impact on the end results (Breusch \& Pagan, 1980; Pesaran, 2004). Cross-sectional dependency has an impact on unit root tests and panel cointegration tests that will be realized. Since this study involves 10 years with 300 observations in total, is not eligible for longterm co-integration relationship and relation of causality analysis. We have adopted the Pesaran CD test to further evaluate cross-sectional dependency and the existence of stationarity, in order to avoid non-stationarity in the unit root tests. The Pesaran CD test is appropriate where $t$ is smaller than $n$ (Pesaran, 2004). The Pesaran CD test statistics are presented in Table 8.

Table 8: Pesaran CD Test Statistics

\begin{tabular}{|l|l|l|l|}
\hline Variable & Pesaran CD Statistic & d.f & $\mathrm{p}$ \\
\hline EPS & 986.056 & 435 & $0.000^{*}$ \\
\hline HSF & 1442.055 & 435 & $0.000^{*}$ \\
\hline F 1 & 668.448 & 435 & $0.0027^{*}$ \\
\hline F $~$ & 558.7891 & 435 & $0.0043^{\star}$ \\
\hline F 3 & 347.258 & 435 & $0.0021^{\star}$ \\
\hline F $~$ & 857.058 & 435 & $0.001^{*}$ \\
\hline F5 & 966.3411 & 435 & 0.0026 \\
\hline
\end{tabular}

Based on the results of the Pesaran CD test, all null hypothesis, which states that inter-variable independency exists, is rejected. In this model, the companies that form the panel have crossdependency for all the independent variables. Accordingly, a change in one of the companies that form the model will affect the same variable in other companies as well.

\subsubsection{Unit Root Tests}

We have adopted four different unit root tests based on the cross-sectional dependency results of the Pesaran CD test. The unit root statistics are reported under the Table 9, whereas, the categorized time graphics of the independent variables are shown in Figure 3. 
Table 9: Unit Root Tests

\begin{tabular}{|c|c|c|c|c|c|c|c|c|}
\hline \multirow{2}{*}{ Variable } & \multicolumn{2}{|c|}{ Levin, Lin \& Chu t } & \multicolumn{2}{|c|}{ Im, Pesaran and Shin W-stat } & \multicolumn{2}{|c|}{ ADF - Fisher Chi-square } & \multicolumn{2}{|c|}{ PP - Fisher Chi-square } \\
\hline & Statistic & $p$ value & Statistic & p value & Statistic & p value & Statistic & $p$ value \\
\hline EPS & -11.571 & 0.000 & -1.647 & 0.049 & 76.858 & 0.070 & 64.353 & 0.327 \\
\hline D(EPS) ${ }^{*}$ & -10.461 & 0.000 & -4.885 & 0.000 & 132.368 & 0.000 & 244.269 & $0.000^{*}$ \\
\hline HSF & -1.872 & 0.030 & 0.878 & 0.812 & 62.404 & 0.390 & 56.914 & 0.589 \\
\hline $\mathrm{D}(\mathrm{HSF})^{\star}$ & -4.744 & 0.000 & -2.321 & 0.010 & 93.021 & 0.004 & 183.694 & $0.000^{*}$ \\
\hline $\mathrm{F}^{*}{ }^{\star}$ & -8.022 & 0.000 & -3.003 & 0.001 & 101.601 & 0.000 & 133.477 & 0.000 \\
\hline F2* & \begin{tabular}{|l|}
-50.849 \\
\end{tabular} & 0.000 & -7.492 & 0.000 & 90.811 & 0.000 & 102.379 & 0.000 \\
\hline $\mathrm{F}^{*}{ }^{*}$ & -7.373 & 0.000 & -2.864 & 0.002 & 99.159 & 0.000 & 138.320 & 0.000 \\
\hline F4 & 0.120 & 0.548 & 0.370 & 0.644 & 61.008 & 0.439 & 106.293 & $0.000^{*}$ \\
\hline $\mathrm{D}(\mathrm{F} 4)^{*}$ & 0.386 & 0.005 & -1.778 & 0.037 & 93.230 & 0.003 & 312.565 & 0.000 \\
\hline F5 & -0.494 & 0.310 & 1.180 & 0.881 & 51.941 & 0.761 & 92.100 & 0.004 \\
\hline $\mathrm{D}(\mathrm{F} 5)^{*}$ & -6.344 & 0.000 & -2.832 & 0.002 & 103.384 & 0.000 & 235.279 & 0.000 \\
\hline
\end{tabular}

$\mathrm{D}(\mathrm{X})$ : First Differencing of Variable X. ${ }^{*}$ Represents statistical significance at a $\% 95$ confidence level.

EPS

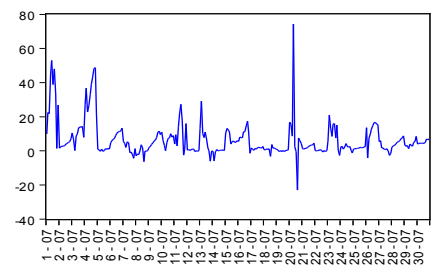

F5

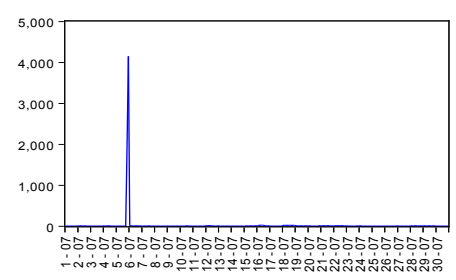

HSF

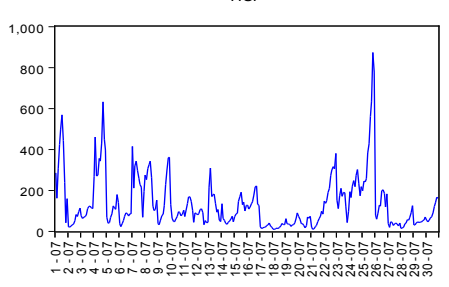

F1

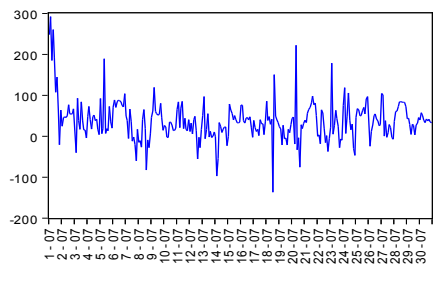

$\mathrm{F} 4$

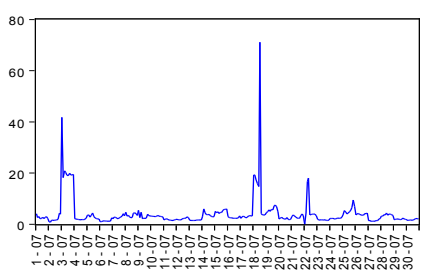

F3

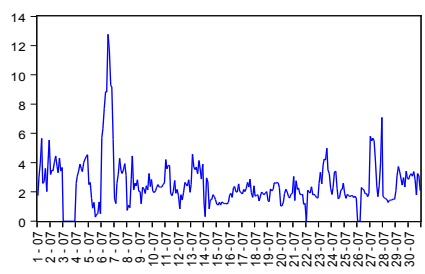

F2

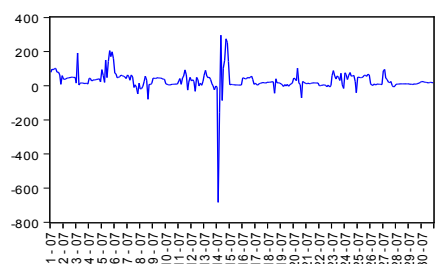

Figure 3: Unit Based Categorized Time Graphs

The null hypothesis for unit root tests is that the series don't have a unit root whereas the alternative hypothesis is that the series contains at least one unit root, which means non-stationarity. Since all 
the series have cross-dependency it would be safer to evaluate unit root existence with four different unit root tests. For the unit root test presented in Table 10, if the majority test accepts the nonexistence of unit root in the series, it has been acknowledged that the series does not have a unit root. In the case of equalization or existence of tests that reject the null hypothesis in the majority, series are subjected to differencing and unit root tests are re-run.

As it can be observed from Table 9, the variables EPS, HSF, F4, and F5 are not stationary at surface level. However, after the first differencing they became stationary. Rests of the variables are stationary as is. The models are updated based on the first differencing of said variables. The updated models are presented below.

$d(E P S)_{i t}=\beta_{0}+\beta_{1} F 1_{i t}+\beta_{2} F 2_{i t}+\beta_{3} F 3_{i t}+\beta_{4} d(F 4)_{i t}+\beta_{5} d(F 5)_{i t}+\beta_{6} E Z R_{i t}+\varepsilon_{i t}$

$d(H S F)_{i t}=\beta_{0}+\beta_{1} F 1_{i t}+\beta_{2} F 2_{i t}+\beta_{3} F 3_{i t}+\beta_{4} d(F 4)_{i t}+\beta_{5} d(F 5)_{i t}+\beta_{6} E Z R_{i t}+\varepsilon_{i t}$

Lastly, before the model estimation is made, we need to determine whether to use a random-effects model or a fixed effect model. We have adopted the Hausman test and its statistics to determine the estimation model to be used. The Hausman test statistic hypothesis is;

$H_{0}:$ Random effects model is more efficient than the fixed effects model,

$H_{1}$ : Fixed effects model is more efficient than the random effects model.

Hausman test statistics are presented in Table 10.

Table 10: Hausman Test Statistics

\begin{tabular}{|l|l|l|l|}
\hline Model & Chi-square value & d.f & p value \\
\hline 1. Model & 30.366 & 6 & $0.000^{*}$ \\
\hline 2. Model & 4.455 & 6 & 0.615 \\
\hline
\end{tabular}

The Hausman statistics showed that for the first model fixed effects model would be more efficient whereas for the second model random effect model is more efficient. Accordingly, for the first model $H_{0}$ is rejected although it is accepted for the second model.

\subsubsection{Model Estimations}

During the model estimations it has been observed that all models have heteroscedasticity problem and in solution, all estimations were made in white process. The examination of Heteroscedasticity Wald test is adopted for fixed effects model and Levene Brown \& Forstyhe tests for the random effects model.

For the assumption of non-autocorrelation Baltagin Wu LBI test is adopted for fixed effects model and Lagrange Multiplier test for random effects model. We have not observed any non-autocorrelation and accordingly made no further resolution. 


\subsubsection{First Model Estimation}

$d(E P S)_{i t}=\beta_{0}+\beta_{1} F 1_{i t}+\beta_{2} F 2_{i t}+\beta_{3} F 3_{i t}+\beta_{4} d(F 4)_{i t}+\beta_{5} d(F 5)_{i t}+\beta_{6} E Z R_{i t}+\varepsilon_{i t}$

The estimation results of the first model with fixed effects model are presented in Table 11.

Table I I: First Model Estimation Results

\begin{tabular}{|l|l|l|l|l|}
\hline Variable & Coefficient & Standard Error & t-statistics & p value \\
\hline F1 & 0.084 & 0.010 & 8.179 & $0.000^{*}$ \\
\hline F2 & 0.009 & 0.006 & 1.396 & 0.163 \\
\hline F3 & 0.507 & 0.399 & 1.272 & 0.204 \\
\hline F4 & 0.117 & 0.089 & 1.320 & 0.187 \\
\hline F5 & 0.000 & 0.001 & 0.242 & 0.808 \\
\hline EZR & 1.46 & 0.730 & 2.00 & $0.004^{*}$ \\
\hline R-Square & 0.24 & Adjusted R-Square & 0.22 & \\
\hline F & 15.777 & $\mathrm{~F}(\mathrm{p})$ & $0.0000^{*}$ & \\
\hline
\end{tabular}

Dependent Variable $=\mathrm{d}(\mathrm{ESP}),{ }^{\star}$ Represents statistical significance at $\% 95$ confidence level

Based on the F probability value, it can be said that the model is statistically significant. The independent variables of the model can account for $\% 22$ of the changes in the dependent variable. Once the variables are evaluated one by one it can be concluded that the F1 independent variable, which is composed of ROA, ROE and YYG ratios, and the EZR (mandatory IR), has statically significant and positive effect on the dependent variable of EPS. In other words, it can be stated that mandatory IR has a statistically significant effect on the dependent variable of Earnings Per Share.

\subsubsection{Second Model Estimation}

$d(H S F)_{i t}=\beta_{0}+\beta_{1} F 1_{i t}+\beta_{2} F 2_{i t}+\beta_{3} F 3_{i t}+\beta_{4} d(F 4)_{i t}+\beta_{5} d(F 5)_{i t}+\beta_{6} E Z R_{i t}+\varepsilon_{i t}$

The estimation results of the second model with random effects model are presented in Table 12.

Table I2: Second Model Estimation Results

\begin{tabular}{|l|l|l|l|l|}
\hline Variable & Coefficient & Standard Error & t-statistics & $\mathbf{p}$ \\
\hline F1 & 0.525 & 0.124 & 4.236 & $0.000^{*}$ \\
\hline F2 & 0.013 & 0.079 & 0.166 & 0.867 \\
\hline F3 & 0.121 & 4.892 & 0.024 & 0.980 \\
\hline F4 & 1.059 & 1.074 & 0.986 & 0.324 \\
\hline F5 & 0.001 & 0.017 & 0.880 & 0.379 \\
\hline EZR & 3.09 & 1.696 & 0.954 & $0.000^{*}$ \\
\hline R-Sqaure & 0.34 & Adjusted R-Square & 0.32 & \\
\hline F & 6.344 & $\mathrm{~F}(\mathrm{p})$ & $0.0000^{*}$ & \\
\hline
\end{tabular}

Dependent Variable $=\mathrm{d}(\mathrm{HSF}),{ }^{\star}$ Represents statistical significance at $\% 95$ confidence level 
Based on the F probability value, it can be said that the model is statistically significant. The independent variables of the model can account for $\% 32$ of the changes in the dependent variable. Once the variables are evaluated one by one it can be concluded that the F1 independent variable, which is composed of ROA, ROE and YYG ratios, and the EZR (mandatory IR), has statically significant and positive effect on the dependent variable of HSF. In other words, it can be stated that mandatory IR has a statistically significant effect on the dependent variable of Stock Price Valuations.

\section{Conclusion}

Interest in the disclosure of non-financial information has been steadily growing after the downfall of the global financial crisis in 2008. The introduction integrated reporting framework introduced a holistic report, which combines financial and non-financial information, as well as including forward-looking information of a company. The adaptation of IR requires a corporate-wide change to create value for all stakeholders to promote corporate sustainability.

In this paper, we have adopted a panel data analysis to test the effects of mandatory IR implementation on companies listed in the Johannesburg Stock Exchange from a financial point of view. The connection was established through a panel data analysis on two separate models composed of financial ratios, between the years of 2007 and 2016 using a dummy variable starting from 2011 to incorporate the commencement of mandatory IR. This study aims to provide evidence regarding the connection between IR and financial viability of a company for a continuous period of 10 years.

The results of this study show parallel results with Gupta and Modise's (2012) work that had statistically showed meaningful relationships between long-term stock price-dividend and price-earnings ratios. The results have proved the validity of $H_{1}$ hypothesis. Additionally, findings support the conclusions derived by Baboukardos and Rimmel (2016). The F1 variable being statistically meaningful for both models is in line with the findings of (Jitmaneeroj, 2017). Moreover, our results are in parallel with the existing studies in the literature on stock pricings by Rapach and Wohar (2005) and Campbell and Schiller (1988).

Lastly, both models show statistical meaningfulness for the use of IR on stock prices and earnings per share ratios of the companies. The empirical results are important in a time where the validity, practicality, and effectiveness of IR are being largely criticized. As the sole reason of IR is to promote corporate sustainability in the long-term, empirical studies need to be repeated as larger data sets start to form.

As a conclusion, this empirical study provides initial evidence on the effects of mandatory integrated reporting implementation on stock price valuations and earnings per share. The results support the argument of IIRC regarding promoting long-term corporate sustainability. Even though the current format of IR is in an ever-changing status based on stakeholder's demand for information, the results illuminate prospective results of this newly established reporting structure. 


\section{References}

Basu, S. (1977). Investment erformance of common stocks in relation to their price-earnings ratios: A test of the efficient market hypothesis. The Journal of Finance, 32(3), 663-682. https://doi. org/10.1111/j.1540-6261.1977.tb01979.x

Beck, C., Dumay, J., \& Frost, G. (2017). In pursuit of a "Single Source of Truth": Fromt threatened legitimacy to integrated reporting. Journal of Business Ethics, 141(1), 191-205. https://doi.org/10.1007/s10551-0142423-1.

Breusch, T. S., \& Pagan, A. R. (1980). The Lagrange multiplier test and its applications to model specification in econometrics. The Review of Economic Studies, 47(1), 239. https://doi.org/10.2307/2297111.

Burke, J. J., \& Clark, C. E. (2016). The business case for integrated reporting: Insights from leading practitioners, regulators, and academics. Business Horizons, 59(3), 273-283. https://doi.org/10.1016/j. bushor.2016.01.001.

Bushee, B. J., \& Christopher, F. N. (2000). Corporate disclosure practices, institutional investors, and stock return volatility. Journal of Accounting Research, 38, 171-202.

Campbell, J. Y. (1999). Asset prices, consumption, and the business cycle. In Handbook of Macroeconomics (pp. 1231-1303). Elsevier. https://doi.org/10.1016/S1574-0048(99)10032-6.

Dumay, J., Bernardi, C., Guthrie, J., \& Demartini, P. (2016). Integrated reporting: A structured literature review. Accounting Forum, 40(3), 166-185. https://doi.org/10.1016/j.accfor.2016.06.001.

Easton, P. D. (2004). PE ratios, PEG ratios, and estimating the implied expected rate of return on equity capital, The Accounting Review, 79(1), 73-95. https://doi.org/10.2308/accr.2004.79.1.73.

Eccles, R. G., \& Krzus, M. P. (2010). One report: Integrated reporting for a sustainable Strategy.

Eccles, R. G., Serafeim, G., \& Armbrester, P.(2012). Integrated Reporting in South Africa.

Eccles, R. G., Serafeim, G., \& Krzus, M. P. (2011). Market Interest in nonfinancial information. Journal of Applied Corporate Finance, 23(4), 113-127. https://doi.org/10.1007/978-1-4614-9173-6.

Eccles, R. G., \& Serafeim, G. (2013). A tale of two stories: Sustainability and the quarterly earnings call. Journal of Applied Corporate Finance, 25(3), 8-19.

Fărcas, T. V. (2015). Development of corporate reporting over time : From a traditional system to an Integrated System. Audit Financiar, 4(124), 106-113.

Flower, J. (2015). The international integrated reporting council: A story of failure. Critical Perspectives on Accounting, 27, 1-17. https://doi.org/10.1016/j.cpa.2014.07.002.

Gregory Mankiw, N., \& Shapiro, M. D. (1986). Do we reject too often?: Small sample properties of tests of rational expectations models. Economics Letters, 20(2), 139-145. https://doi.org/10.1016/0165-1765(86)901618.

Gupta, R., \& Modise, M. P. (2012). Valuation ratios and stock return predictability in South Africa: Is it there? Emerging Markets Finance and Trade, 48(1), 70-82. https://doi.org/10.2753/REE1540-496X480104.

Havlová, K. (2015). What integrated reporting changed: The case study of early adopters. Procedia Economics and Finance, 34(15), 231-237. https://doi.org/10.1016/S2212-5671(15)01624-X.

IoDSA. (2013). Practice Notes: King III reporting in terms of the JSE Listing Requirements. Johannesburg.

Jitmaneeroj, B. (2017). The impact of dividend policy on price-earnings ratio. Review of Accounting and Finance, 16(1), 125-140. https://doi.org/10.1108/RAF-06-2015-0092.

King Comittee. (2002). King report on corporate governance for South Africa 2002. Retrieved from http:// library.ufs.ac.za/dl/userfiles/documents/Information_Resources/KingII Final doc.pdf. 
King Comittee. (2009). King Code of Governance Principles for South Africa 2009. Retrieved from http://c. ymcdn.com/sites/www.iodsa.co.za/resource/collection/94445006-4F18-4335-B7FB-7F5A8B23FB3F/ King_III_Code_for_Governance_Principles_.pdf.

Kirby, C. (1997). Measuring the predictable variation in stock and bond returns. Review of Financial Studies, 10(3), 579-630. https://doi.org/10.1093/rfs/10.3.579.

Kothari, S. P., \& Shanken, J. (1997). Book-to-market, dividend yield, and expected market returns: A timeseries analysis. Journal of Financial Economics, 44(2), 169-203. https://doi.org/10.1016/S0304405X(97)00002-0.

La Porta, R. (1996). Expectations and the cross-section returns of stock. The Journal of Finance, 51(5), 17151742. https://doi.org/10.1111/j.1540-6261.1996.tb05223.x.

Lewellen, J. (2004). Predicting returns with financial ratios. Journal of Financial Economics, 74(2), 209-235. https://doi.org/10.1016/j.jfineco.2002.11.002.

Maas, K., Schaltegger, S., \& Crutzen, N. (2016). Advancing the integration of corporate sustainability measurement, management and reporting. Journal of Cleaner Production, 133, 859-862. https://doi. org/10.1016/j.jclepro.2016.06.006.

Marin-Garcia, J. A., \& Tomas, J. M. (2016). The integrated reporting: A presentation of the current state of art and aspects of integrated reporting that need further development. Intangible Capital, 12(1), 357-389. https://doi.org/10.3926/ic.476.

Molodovsky, N. (1955). Stock prices and current earnings. Financial Analysts Journal, 11(4), 83-94. https://doi. org/10.2469/faj.v11.n4.83.

Ocean Tomo. (n.d.). Intangible asset market value study. Retrieved November 21, 2017, from http://www. oceantomo.com/intangible-asset-market-value-study/.

Ou, J. A., \& Penman, S. H. (1989). Financial statement analysis and the prediction of stock returns. Journal of Accounting and Economics, 11(4), 295-329. https://doi.org/10.1016/0165-4101(89)90017-7.

Pesaran, M. H. (2004). General diagnostic tests for cross section dependence in panels. Cesifo Working Paper No. 1229. Apollo - University of Cambridge Repository. https://doi.org/10.17863/cam.5113

Rapach, D. E., \& Wohar, M. E. (2005). Valuation ratios and long-horizon stock price predictability. Journal of Applied Econometrics, 20(3), 327-344. https://doi.org/10.1002/jae.774.

Rikanovic, M. (2005). Corporate disclosure strategy and the cost of capital - An empirical study of large listed German Corporations. University of St.Gallen.

Schulschenk, J. (2012). Corporate Governance Research Programme: Interview Summary Report.

Stewart, L. S. (2015). Growing demand for ESG information and standards: Understanding corporate opportunities as well as risks. Journal of Applied Corporate Finance, 27(2), 58-63. 